\title{
A review on Fagopyrum esculentum: A potential medicinal plant
}

\author{
Prof Dr Ali Esmail Al-Snafi \\ Department of Pharmacology, College of Medicine, Thi qar University, Iraq.
}

\begin{abstract}
Fagopyrum esculentum contained alkaloids, amino acids, anthraquinones, carbohydrates, flavonoids, phlobatannins and tannins. The nutritional analysis of Fagopyrum esculentum flour and bran revealed that they contained starch: 55, 75 and 18\%; proteins: 12, 6 and 36\%; lipids: 4, 1 and 11\%; soluble carbohydrates: 2, 1 and 6\%; total dietary fibers: 7, 3 and 15\%; and ash: 2, 1 and 7\% respectively. The pharmacological studies showed that Fagopyrum esculentum possessed antioxidant, antiinflammatory, cardiovascular, hypolipidemic, antigenotoxic, antidiabetic, reno-protective, anticancer, antimicrobial, wound healing, antistress, protected memory impairment and photoprotective effects. This review will highligh the chemical constituents and pharmacological effects of Fagopyrum esculentum.
\end{abstract}

Keywords: Fagopyrum esculentum, contents, constituents, pharmacology

\section{I-INTRODUCTION:}

Plants generally produce many secondary metabolites which were constituted an important source of many pharmaceutical drugs[1]. Many previous reviews revealed the wide range of the pharmacological and therapeutic effects of medicinal plants [2-50]. Previous studies showed that Fagopyrum esculentum contained alkaloids, amino acids, anthraquinones, carbohydrates, flavonoids, phlobatannins and tannins. The nutritional analysis of Fagopyrum esculentum light coloured flour and bran revealed that they contained starch: 55, 75 and 18\%; proteins: 12, 6 and 36\%; lipids: 4, 1 and 11\%; soluble carbohydrates: 2,1 and 6\%; total dietary fibers: 7, 3 and 15\%; and ash: 2, 1 and 7\% respectively. The pharmacological studies showed that Fagopyrum esculentum possessed antioxidant, antiinflammatory, cardiovascular, hypolipidemic, antigenotoxic, antidiabetic, reno-protective, anticancer, antimicrobial, wound healing, antistress, protected memory impairment and photoprotective effects. This review will highligh the chemical constituents and pharmacological effects of Fagopyrum esculentum.

\section{Synonyms:}

Fagopyrum cereale Raf., Fagopyrum dryandrii Fenzl, Fagopyrum emarginatum Moench, Fagopyrum emarginatum (Roth) Meisn., Fagopyrum emarginatum var. kunawarense Meisn., $\quad$ Fagopyrum esculentum subsp. ancestralis Ohnishi, Fagopyrum sarracenicum Dumort., Fagopyrum vulgare T. Nees and Polygonum fagopyrum L., Polygonum[51].

Taxonomic classification:

Kingdom: Plantae, Subkingdom: Viridiplantae, Superdivision: Embryophyta, Division: Tracheophyta, Subdivision: Spermatophytina, Class: Magnoliopsida, Superorder: Caryophyllanae, Order: Caryophyllales, Family: Polygonaceae, Genus: Fagopyrum, Species: Fagopyrum esculentum [52].

\section{Common names:}

Arabic: Al-Hintta Al-Swdaa; Chinese: qiao mai; English: buckwheat, common buckwheat, Japanese buckwheat, silverhull buckwheat; French: blé noir, bouquette, renouée, sarrasin, sarrasin commun; German: Buchweizen, Heidekorn; Hindi: Koti; Italian: faggina, fagopiro, grano saraceno, Sarasin; Japanese: soba; Korean: memil; Russian: grečicha kul'turnaja, grečicha posevnaja; Portuguese: trigosarraceno; Spanish: alforfón, grano sarraceno, grano turco, trigo-sarraceno; Swedish: bovete[53].

\section{Distribution:}

Common buckwheat is one of the oldest domesticated crops from Asia. The origin of its domestication dates back about 4000 to 5000 years in South China. From Southern China, cultivated buckwheat was introduced to other Asian countries, Europe, Africa and North and South America[54].Now the plant was distributed in Africa (Kenya, Tanzania, Uganda, Ethiopia, Zimbabwe, South Africa, Zaire, Reunion and Botswana); Asia (China, Japan, Korea, Kazakhstan, Mongolia, Russian Federation, Iraq, India, Nepal, Pakistan, Myanmar, Thailand and Vietnam); Europe (Belarus, Latvia, Lithuania, Russian Federation, Ukraine, Poland, Austria, Germany, Denmark, Sweden, Bulgaria; Australia: Australia and New Zealand); Northern America (Canada and United States) and Southern America (Brazil and Cuba) [53]. 
However, China, Russian Federation, Ukraine, Republic of Moldova, Kazakhstan, France, USA, Poland, Brazil, Japan, Canada, Korea and Bhutan produced the larger quantities of buckwheat in the worlds from 1961-2010[54].

\section{Description:}

Annual herb, stems green or red when mature, erect, $30-90 \mathrm{~cm}$ tall, branched above, glabrous or papillate on one side. Petiole 1.5-5 cm; leaf blade triangular, $2.5-7 \times 2-5 \mathrm{~cm}$, both surfaces papillate along veins, base cordate or nearly truncate, apex acuminate; ocrea caducous, ca. $5 \mathrm{~mm}$, membranous, oblique, not ciliate. Inflorescence axillary or terminal, racemose or corymbose; peduncles $2-4 \mathrm{~cm}$, papillate along one side; bracts green, ovate, $2.5-3 \mathrm{~mm}$, margin membranous, each 3- or 5-flowered. Pedicels longer than bracts, not articulate. Perianth pink or white; tepals elliptic, 3-4 mm. Anthers pinkish. Styles heterostylous. Achenes exceeding persistent perianth, dark brown, opaque, ovoid, sharply trigonous, 5-6 mm, surfaces flat[55].

\section{Traditional uses:}

Buckwheat is consumed by humans and animals in different forms corresponding to different types of production: flour, whole seeds, sprouts, shoots and honey. Honey is a major by-product of buckwheat cultivation with a dark colour and strong taste. It is used to sweeten foods, chiefly pastries. One ha of buckwheat produced an average $125 \mathrm{~kg}$ honey and the best cultivars produce 150 to $300 \mathrm{~kg} / \mathrm{haSprouts}$ can be consumed in salads 2 days after germination, and young shoots can be eaten 10 days later. Young plantlets may still be harvested to make juice three weeks after germination [54]. Leaves cooked in iron vessel were given to anemic patients. The cooked leaves were also used to cure constipation [56].The leaf of buckwheat was also used traditionally for choking, ulcer, haemostasis, for bathing wounds, to improve the functions of sight and hearing, and to keep adverse energy down. The plant was also used traditionally to treat hypertension, diabetes, peridontitis and gum bleeding [57].

\section{II-CHEMICAL CONSTITUENTS:}

The preliminary phytochemical analysis of Fagopyrum esculentum showed that it contained alkaloids, amino acids, anthraquinones, carbohydrates, flavonoids, phlobatannins and tannins [58].

Buckwheat was consumed by humans and animals in different forms. Buckwheat seeds characterized by high nutritive value. The nutritional analysis of buckwheat groats, light coloured flour and bran showed that they contained starch: 55, 75 and 18\%; proteins: 12,6 and 36\%; lipids: 4, 1 and 11\%; soluble carbohydrates: 2, 1 and 6\%; total dietary fibers: 7, 3 and $15 \%$; and ash: 2,1 and $7 \%$ respectively [54].

Buckwheat seeds (Fagopyrum esculentum Moench) were milled into 23 fractions: seven fine flours, three coarse flours, four small semolina, two big semolina, six bran, and one husk fraction. A considerable variation in gross chemical composition was found among the milling fractions. The protein content varied from 4.4 to $11.9 \%(\mathrm{db})$ in flours and from 19.2 to $31.3 \%$ in bran fractions; starch varied from 91.7 to $70.4 \%$ in flours and from 42.6 to 20.3 in bran. The percentage of soluble dietary fiber/ total dietary fiber was higher in flours than in semolina and bran fractions [59]. Average mineral and vitamin contents of buckwheat were: calcium 110 $\mathrm{mg} / 100 \mathrm{~g}$, iron $4 \mathrm{mg} / 100 \mathrm{~g}$, magnesium $390 \mathrm{mg} / 100 \mathrm{~g}$, phosphorus $330 \mathrm{mg} / 100 \mathrm{~g}$, potassium $450 \mathrm{mg} / 100 \mathrm{~g}$, copper $0.95 \mathrm{mg} / 100 \mathrm{~g}$, manganese $3.37 \mathrm{mg} / 100 \mathrm{~g}$, zinc $0.87 \mathrm{mg} / 100 \mathrm{~g}$, thiamine $3.3 \mathrm{mg} / \mathrm{kg}$, riboflavin 10.6 $\mathrm{mg} / \mathrm{kg}$, pantothenic acid $11.0 \mathrm{mg} / \mathrm{kg}$, choline $440 \mathrm{mg} / \mathrm{kg}$, niacin $18.0 \mathrm{mg} / \mathrm{kg}$, pyridoxine $1.5 \mathrm{mg} / \mathrm{kg}$ and tocopherols $40.0 \mathrm{mg} / \mathrm{kg}$ [57].The percent of amino acid composition of proteins of whole buckwheat and buckwheat groats (respectively) were: lysine 6.0 and 5.9, histidine 2.6 and 2.6, ammonia 2.1 and 1.9, arginine 9.2 and 10.0, aspartic acid 11.4 and 11.4, threonine 4.0 and 3.8, serine 4.9 and 4.6, glutamic acid 18.5 and 19.3, proline 3.8 and 3.8 , cystine 1.6 and 1.8 , glycine 6.6 and 6.2 , afanine 4.3 and 4.4 , valine 5.3 and 4.9 , methionine 2.3 and 2.8, isoleucine 4.0 and 3.7 , leucine 6.7 and 6.2, tyrosine 2.0 and 2.1, phenylalanine 4.8 and 4.8, (Lys. + Tyr. + Met.) 12.4 and 12.4\% [57].The flavonoids contents were $19.64 \mu \mathrm{g} / 250 \mu \mathrm{g}$ of dry powder $(7.856 \%)$. The phenolics contents were $0.80 \mu \mathrm{g} / 25.97 \mu \mathrm{g}$ of dry powder $(3.08 \%)$ [58].

The rutin content was higher than quercetin in buckwheat seeds. Rutin content was in the range from 0.05 to $1.35 \%$ of buckwheat seeds. Quercetin content varied from 0.01 to $0.17 \%$ and in some common buckwheats it was even difficult to detect, hyperoside $0.18-0.37 \%$ and chlorogenic acid $4.09-5.57 \%$. It was found that amino acid contents were around 1.79 to $12.65 \%$ (farina) and 5.74 to $7.89 \%$ (bran) in common buckwheats [60-61].

Chlorogenic acid, catechin, isoorientin, orientin, rutin, vitexin, and quercitrin were isolated from Fagopyrum esculentum. The accumulation of these metabolites increased the antioxidant activity of the sprouts. Their accumulation can be enhanced by stimulation of the phenylpropanoid pathway by methyl jasmonate treatment [62].

Four catechins and rutin were isolated from ethanol extracts of Fagopyrum esculentum groats. The structures of these catechins were established as $(-)$-epicatechin, $(+)$-catechin 7-O- $\beta$-D-glucopyranoside, $(-)$-epicatechin $3-$ $O-p$-hydroxybenzoate, and $(-)$-epicatechin 3-O-(3,4-di-O-methyl) gallate [63].Chemical analysis showed that 
the plant also contained, cyclitol: (fagopyritol A1, fagopyritol A2, fagopyritol A3, fagopyritol B1, fagopyritol B2 and fagopyritol B3); triterpenoids: (olean-12-en-3-ol and urs-12-en-3-ol); steroids: (6-hydroxystigmasta4,22-dien-3-one, S-methylcholesterol, stigmast-5-en-3-ol, stigmast-5,24-dien-3-ol and trans-stigmast-5,22dien-3-ol); fatty Acids: (6, 7-dihydroxy-3,7-dimethyl-octa-2(Z),4(E)-dienoic acid, 6, 7-dihydroxy-3,7dimethyl-octa-2(E),4(E)-dienoic acid and 4, 7-dihydroxy-3,7-dimethyl-octa-2(E), 5(E)-dienoic acid); $\gamma$ tocopherol and squalene [64-67].Buckwheat has a strong characteristic aroma. Volatiles from a freshly ground buckwheat flour were extracted by different methods The compounds with the highest contribution to the buckwheat aroma were: 2,5-dimethyl-4-hydroxy-3(2 H )-furanone, (E, E)-2,4-decadienal, phenylacetaldehyde, 2-methoxy-4-vinylphenol, ( E )-2-nonenal, decanal, hexanal and salicylaldehyde (2-hydroxybenzaldehyde) [68]. A water soluble protein with a molecular weight of 57000, was isolated from the tartary buckwheat (TBWSP). CD analysis showed that TBWSP31 has $\alpha$-helix (33.9\%), $\beta$-sheet $(22.8 \%), \beta$-turn $(11.3 \%)$, and random coil $(32.0 \%)$ [69].

\section{Antioxidant effect:}

\section{III-PHARMACOLOGICAL EFFECTS:}

The antioxidant potential of Fagopyrum esculentum was evaluated by DPPH assay and reducing power method. Fagopyrum esculentum showed strong antioxidant activity. The highest antioxidant activity was found at concentration $1 \mathrm{mg} / \mathrm{ml}(81.64 \%)$ [58].Buckwheat seed components were evaluated for antioxidant and free radical-scavenging activities using solvents of different polarities to isolate components from hulls and groats. The highest activity was observed for the methanolic extract. It was also observed that the radical scavenging effectiveness of extracts was concentration dependent. Analysis revealed the presence of tocopherols in the hexane extract, while methanolic extracts were rich in phenolic acids and flavonoids [70]. The antioxidant activity of catechins isolated from Fagopyrum esculentum [(-)-epicatechin, (+)-catechin 7-O$\beta$-D-glucopyranoside, (-)-epicatechin 3-O-p-hydroxybenzoate, and (-)-epicatechin 3-O-(3,4-di- $O$-methyl) gallate] was higher than that of rutin [63]. The extract of buckwheat herb was compared to rutin, which was the main constituent of the extract, regarding their antioxidant and radical scavenging activity. The antioxidant activity was quantified regarding the reactivity versus the 1,1-diphenyl-2-picryl-hydrazyl radical (DPPH). In the DPPH assay, the extract had significantly better antioxidant activity than pure rutin. The use of the extract from buckwheat herb seems to be more beneficial than the use of pure rutin because of the presence of minor phenolic compounds in the extract [61].Buckwheat hull extract scavenged superoxide anion produced in the xanthine/ xanthine oxidase system $\left(\mathrm{IC}_{50}=11.4 \mathrm{microg}\right.$ phenolic compound $/ \mathrm{ml}$ ), and strongly inhibited autoxidation of linoleic acid $\left(\mathrm{IC}_{50}=6.2\right.$ microg phenolic compound $/ \mathrm{ml}$ ). Low-density lipoprotein (LDL) oxidation induced by $\mathrm{Cu}^{2+}$ ion was also protected by buckwheat hull extract. In the animal experiment, mice were fed a standard diet supplemented with $0.75 \%$ buckwheat hull extract for 14 days. In blood, liver and brain of the mice, TBARS and fluorescent substance concentration were significantly decreased compared with those of non-treated mice. SOD activity in serum was also significantly rose by buckwheat hull extract treatment. Buckwheat hull extract was shown to be effective for protecting biological systems against various oxidative stresses in vitro, and to have antioxidant activity in vivo [71].Buckwheat honey samples were tested for inhibition of reactive oxygen species (ROS) production by activated human PMNs, antioxidant activity (scavenging of superoxide anion in a cell-free system) and inhibition of human complement (reducing levels of ROS by limiting formation of complement factors that attract and stimulate PMNs). Most honey samples were shown to be active inhibitors of reactive oxygen species [72]. The culture and buckwheat dough matrix was evaluated with respect to total phenolic content and antioxidant potential. The total phenolic content was increased from 2.73 to $7.64 \mathrm{mg} \mathrm{GAE}($ Gallic Acid Equivalence)/g. Antioxidant potential of fermented buckwheat also showed an increased percentage of 2,2-diphenyl-2-picrylhydrazyl scavenging activity from $44.32 \%$ to $88.98 \%$ and ferric reducing antioxidant power potential from 14.43 to $25.68 \mu \mathrm{M} \mathrm{Fe}$ (II)/g after $72 \mathrm{~h}$ of fermentation [73]. The effect of Buckwheat extract (TBWE) on anti-adipogenesis and pro-oxidant enzyme in 3T3-L1 adipocytes were studied. TBWE markedly inhibited adipocyte differentiation and ROS production in 3T3-L1 cells compared with control groups. Moreover, TBWE was strongly inhibited adipogenic transcription factor as well as pro-oxidant enzymes. Methyl jasmonate treatment significantly increased the amount of phenolic compound, resulting in the suppression of adipogenesis and ROS production in the 3T3-L1 cells [74].

The acute effect of consumption of $500 \mathrm{ml}$ of water, water with buckwheat honey, black tea, black tea with sugar, or black tea with buckwheat honey, on serum oxidative reactions was examined in 25 healthy men. Antioxidant capacity of human serum samples was measured using different methods: the oxygen radical absorbance capacity (ORAC) assay, ex vivo susceptibility of serum lipoprotein to $\mathrm{Cu}^{2+}$-induced oxidation, and the thiobarbituric acid reactive substances (TBARS) assay. The results showed that the serum antioxidant capacity determined by ORAC, was increased significantly $(\mathrm{p}<0.05)$ by $7 \%$ following consumption of buckwheat honey in water. No significant changes in serum antioxidant capacity could be established after the 
consumption of any of the other beverages. Ex vivo serum lipoprotein oxidation and TBARS values were not significantly altered after consumption of any of the five beverages [75].

\section{Antiinflammatory effect:}

The anti-inflammatory activity of extract of Fagopyrum esculentum was confirmed by oral administration of lipopolysaccharide (LPS) to mice. Inflammatory cytokines (interleukin 6 and tumor necrosis factor alpha) were markedly up-regulated in the spleen and liver from LPS-administrated mice, and combinatory treatment with LPS and the extract of Fagopyrum esculentum decreased the up-regulation of them in both cytokines. Both serum cytokine levels corresponded to their gene expressions in tissues, but no antiinflammatry effect in mice was observed when extract of Fagopyrum esculentum was given intraperitoneally. Oral administration of the extract of Fagopyrum esculentum also showed protective activity to hepatic injury induced by galactosamine/ LPS treatment [76]. The effects of Fagopyrum esculentum was studied on the release of inflammatory mediator and proximal signal events in $\mathrm{F}_{\mathrm{CE}} \mathrm{RI}$-mediated RBL-2H3 cell activation. Fagopyrum esculentum reduced antigen (DNP-HSA)-induced release of histamine, prostaglandin $\mathrm{D}_{2}$ and cysteinyl Leukotriene in IgE-sensitized RBL-2H3 cells. In addition, it inhibited antigen-induced HDC2 and COX-2 and 5-Lipoxygenase mRNA expression in IgE-sensitized RBL-2H3 cells. Fagopyrum esculentum also suppressed antigen-induced $F_{C E} R I \beta$ and $F_{C E}$ RIY subunit mRNA expression in these cells. To identify the mechanisms underpinning the inhibition of release of inflammatory mediators such as histamine and PGD2 and cysLT by Fagopyrum esculentum, the proximal signal events of intracellular $\mathrm{F}_{\mathrm{CE}} \mathrm{RI}$ signaling molecules was examined. Fagopyrum esculentum suppressed antigen-induced phosphorylation of Lyn, Syk, LAT, PLC Y1, PI3K, Akt and cPLA2 [77]. The anti-allergic action of buckwheat grain extract was investigated using rodent experimental models. The oral, intraperitoneal and intradermal administration of buckwheat grain extract significantly inhibited the compound 48/80-induced vascular permeability. Buckwheat grain extract also showed potent inhibitory effect on passive cutaneous anaphylaxis (PCA) activated by anti-dinitrophenyl (DNP) IgE when orally administered. In an in vitro study, buckwheat grain extract possessed inhibitory potential on the 48/80-induced histamine release from rat peritoneal mast cells. Furthermore, buckwheat grain extract inhibited the IL-4 and TNF-alpha mRNA induction by PMA and A23187 in human leukemia mast cells [78].

\section{Cardiovascular and hypolipidemic effects:}

A total of 3542 Mongolians in two adjacent counties of Inner Mongolia, China, were randomly sampled in a cross-sectional study to assess the association of hypertension and dyslipidaemia with lifetime consumption of buckwheat seed as a staple food. A sample group of 961 participants was also examined for fasting serum concentrations of lipids and glucose. The age-adjusted prevalence rate of hypertension in Kulun participants who consumed buckwheat seed as a staple food was $18.22 \%$ ( $95 \%$ confidence interval (CI): $16.95 \%, 19.49 \%$ ), whereas that in Kezhuohou participants, who consumed corn as a staple food, was $23.31 \%$ (95\% CI: $21.92 \%, 24.70 \%)$. A statistically significant difference was found between the two groups $(\mathrm{P}<0.01)$. Age-adjusted prevalence rates in Kulun participants compared with Kezhuohou participants for hypercholesterolaemia, hyper-triglyceridaemia and abnormalities in low-density lipoprotein-cholesterol were 4.02\% (95\% CI: $2.24 \%, 5.80 \%$ ) versus $7.76 \%$ (95\% CI: 5.39\%, 10.13\%; P < 0.01 ), $26.58 \%$ (95\% CI: $22.59 \%$, $30.57 \%$ ) versus $31.04 \%$ (95\% CI: 26.59\%, 35.13\%; P < 0.05$)$ and $4.66 \%$ (95\% CI: $2.75 \%, 6.57 \%$ ) versus $8.81 \%$ (95\% CI: $6.30 \%, 11.32 \%$; P < 0.01), respectively. The results indicated that the consumption of buckwheat seed possessed preventative effect for hypertension and dyslipidaemia in the Pastureland Mongolian population [79].Buckwheat rutin has been found to be able to inhibit angiotensin II (AngII) induced hypertrophy in cultured neonatal rat cardiomyocytes. Myocardial hypertrophy model was made by adding AngII to the medium of cardiac myocytes of neonatal rats, different concentrations of buckwheat rutin were applied to observe their effects by investigation. intracellular $\mathrm{Ca}^{2+}$ level, calcineurin $(\mathrm{CaN})$ activity, the expression of $\mathrm{CaN}$ protein and the proto - oncogene $\mathrm{c}$ - fos mRNA expression. The activities and protein expression of cardiomyocytes $\mathrm{CaN}$, and the expression of proto - oncogene $\mathrm{c}$ - fos mRNA in cultured neonatal rat cardiomyocytes, were effectively decreased by buckwheat rutin [80]. Angiotensin I-converting enzyme (ACE) inhibitory peptide was isolated and identified from buckwheat (Fagopyrum esculentum). The ACE inhibitor was identified to be a tripeptide, Gly-Pro-Pro, having $\mathrm{IC}_{50}$ value of $6.25 \mu \mathrm{g}$ protein/ml, by protein sequencing system and electrospray-LC-mass spectrometry [81].

Sixty-seven male and female patients (22-74 years) with chronic venous insufficiency (CVI) were randomly divided into two groups. They received either buckwheat herb tea (Fagopyrum esculentum) or a placebo tea for a period of 3 months. The main outcome measure was the lower leg volume determined by ultrasound. Subjective symptoms were assessed by a clinical symptom score system. The femoral vein diameters were measured by B-scan sonography. In a subgroup of patients, capillary permeability was determined by cutaneous fluorescence angiography. Although the mean partial leg volume did not change in the treatment group (from 2041 to $2073 \mathrm{ml}$ ), but it increased in the placebo group by $110 \mathrm{ml}$ (from 1972 to $2082 \mathrm{ml}$ ). The 
subjective clinical symptoms were significantly Reduced In Both Groups. The Mean Diameters Of The Femoral Veins Were Reduced And Capillary Permeability Was Improved, But The Changes Were Statistically Insignificant. No Drug-Related Adverse Effects Were Observed [82].The Effect Of High Protein Buckwheat Flour (PBF) Was Investigated On Serum Cholesterol And Body Fat In Rats And On Cholesterol Gallstone Formation In Mice. Animals Were Fed Experimental Diets That Contained Casein, Buckwheat Protein Extract (BWP), Or PBF As A Protein Source (Net Protein Content $200 \mathrm{G} / \mathrm{Kg}$ ). Consumption Of PBF And BWP For 10 Days Caused 33\% And 31\% Decreases, Respectively, In Serum Cholesterol Of Rats Fed Cholesterol-Enriched Diets When Compared With Consumption Of Casein $(\mathrm{P}<0.05)$. Dietary PBF Caused A Significant Decrease In Liver Cholesterol, Whereas Dietary BWP Caused Only A Slight Decrease $(\mathrm{P}>0.05)$. Fecal Excretion Of Neutral And Acidic Steroids In The PBF Group Was Significantly Higher Than Those In The BWP And Casein Groups. Furthermore Consumption Of PBF For 10 Day Significantly Suppressed Adipose Tissue Weight And Hepatic Activity Of Fatty Acid Synthase In Rats Fed Cholesterol-Free Diets Compared With Consumption Of Casein $(\mathrm{P}<0.05)$, Whereas BWP For The Same Period Caused Only A Slight Decrease In Adipose Tissue Weight ( $\mathrm{P}>0.05)$. In Addition, Dietary PBF And BWP Significantly Decreased The Incidence Of Cholesterol Gallstones And Lithogenic Index In Mice Fed Cholesterol-Enriched Diets For 27 Days, Which Was Associated With Increased Fecal Excretion Of Acidic Steroids [83-84].

\section{Antigenotoxic effect:}

The antigenotoxic effect of methanolic extracts of Fagopyrum esculentum and tartary Fagopyrum esculentum flour, containing naturally present rutin, and quercetin was evaluated against tert-butyl hydroperoxide induced DNA damage in human hepatoma cell line (HepG2). Rutin and quercetin content of CB and tartary Fagopyrum esculentum flour extracts was determined by reversed phase-high performance liquid chromatography and antigenotoxic effect of flour extracts, rutin and quercetin were evaluated using the comet assay. Rutin $(100 \mu \mathrm{M})$ and quercetin $(50 \mu \mathrm{M})$ decreased the extent of tert-butyl hydroperoxide induced DNA damage for $51 \%$ and $67 \%$, respectively. Methanolic extracts of Fagopyrum esculentum and tartary Fagopyrum esculentum flour extracts showed high antioxidant capacity and prominent genoprotective ability. Methanolic extracts of Fagopyrum esculentum extract containing up to $0.1 \mu \mathrm{M}$ rutin decreased tert-butyl hydroperoxide induced DNA damage for 34\%, and tartary Fagopyrum esculentum flour extract containing up to $12.64 \mu \mathrm{M}$ rutin, and $2.86 \mu \mathrm{M}$ quercetin decreased tert-butyl hydroperoxide induced DNA damage for $40 \%$ [85].

\section{Renal effect:}

The effects and mechanisms of the overall flavonoids from buckwheat flowers and leaves (TFBFL 200 $\mathrm{mg} / \mathrm{kg}$ / day) on renal damage in type 2 diabetes mellitus (T2DM) were investigated in rats. TFBFL lowered fasting blood glucose, improved insulin resistance, caused creatinine clearance rate, and renal morphological changes, down-regulated the expression of PTP1B in T2DM rats. Based on the results, TFBFL had a significant protective effect on renal damage in T2DM rats. This effect may be due to lowering blood glucose and diminishing renal damage by inhibiting PTP1B expression [86].Rats subjected to partial resection of the parenchyma of the kidney showed reduced radical-scavenging activity in the remaining kidney and increased severity of renal tissue lesions. However, rats given buckwheat extract, improved oxidative stress by restoring the decreased activities of reactive oxygen species-scavenging enzymes such as superoxide dismutase and catalase. The degree of mesangial proliferation, severity of extratubular lesions such as crescents and adhesions, glomerulo-sclerosis index, and severity of tubular interstitial lesions were also improved. Furthermore, rats showed improvement in renal function, as indicated by decreased serum level of creatinine, with a significant decrease in the level of methylguanidine, a uremic toxin produced from creatinine in the presence of hydroxyl radical [87].The ameliorating effect of buckwheat extract was studied in renal injury induced by ischemiareperfusion. In ischemic-reperfused control rats, the activities of antioxidative enzymes in renal tissue and blood and renal parameters deviated from the normal range, indicating dysfunction of the kidneys. When buckwheat extract was given orally for 20 consecutive days before ischemia and reperfusion, the activities of the antioxidation enzymes superoxide dismutase, catalase, and glutathione peroxidase were higher, while thiobarbituric acid-reactive substance levels in serum and renal tissue were lower in the treated rats than in the controls. Buckwheat decreased levels of urea nitrogen and creatinine in serum which indicated a protective effect against the renal dysfunction caused by ischemia and recirculation. Buckwheat extract also possessed protective effect on cultured proximal tubule cells subjected to hypoxia-reoxygenation [88].

\section{Antidiabetic effect:}

Buckwheat bran extracts inhibited sucrase activity in vitro more effectively than buckwheat. Balb/c mice pretreated with buckwheat bran extracts showed dose-dependent reductions of blood glucose, greater than those observed with control mice, within 60 min following oral sucrose administration. Blood glucose levels in mice pretreated with buckwheat extracts were also significantly lower compared to those in control mice within 
30 min following oral administration of sucrose. Rutin, the abundant polyphenols of buckwheat bran extracts, did not lower blood glucose level [89]. The insulin-mimetic activities of a buckwheat concentrate (BWC), dchiro-inositol (D-CI), and myo-inositol (MI), were investigated on insulin signal transduction pathways and glucose uptake with H4IIE rat hepatoma cells. BWC stimulated phosphorylation of p42/44 extracellular-related kinase (p42/44 ERK) and its downstream target, p70 (S6K), on $\operatorname{Thr}(421)$. D-CI, MI, rutin, or its agylcone form, quercetin, did not activate these signal transduction proteins. Phosphorylation of $\mathrm{p} 38$ mitogen-activated protein kinase (p38 MAPK), another target of insulin, was also up-regulated upon BWC treatment. The effects of BWC on glucose uptake were investigated using H4IIE cells. Insulin and D-CI stimulated glucose uptake, whereas BWC inhibited basal and insulin-stimulated glucose uptake. Although results suggested that BWC has insulinmimetic effects on select protein phosphorylation events in H4IIE cells, D-CI and MI were not the active components responsible for these effects. The inhibition of glucose uptake by BWC suggested that buckwheat may affect hepatic glucose metabolism, possibly by inhibiting glucose flux [90]. The nutritional characteristics of buckwheat starch were studied to identify the possibility for reduced postmeal metabolic responses to various buckwheat products. The rate of starch hydrolysis and resistant starch formation in boiled buckwheat groats and in a series of breads, baked with $30-70 \%$ of buckwheat flour or groats, respectively, were evaluated in vitro. In parallel, postprandial glucose and insulin responses and also the satiety score to buckwheat groats and wheat bread with 50\% buckwheat groats as compared with the reference white wheat bread (WWB) were studied in healthy humans. The highest concentration of resistant starch was found in boiled buckwheat groats ( $6 \%$ total starch basis). The resistant starch level in bread products based on different proportions of buckwheat flour or buckwheat groats $(30-70 \%)$ varied from 0.9 to $4.4 \%$. The rate of in vitro amylolysis was significantly lower $(P<0.05)$ in all buckwheat products in comparison with the reference WWB. The calculated hydrolysis indices $(\mathrm{HI})$ were lowest in boiled buckwheat groats $(\mathrm{HI}=50)$ and in bread with $70 \%$ buckwheat groats $(\mathrm{HI}=$ 54). Consumption of boiled buckwheat groats or bread based on wheat flour and $50 \%$ buckwheat groats induced significantly lower postprandial blood glucose and insulin responses compared with the WWB. The calculated glycemic and insulinemic indices for boiled buckwheat groats were 61 and 53 and for the buckwheat bread, 66 and 74, respectively. The highest satiety score was found with boiled buckwheat groats [91]. A total of 3542 Mongolians in two adjacent counties of Inner Mongolia, China, were randomly sampled in a cross-sectional study to assess the association hyperglycaemia with lifetime consumption of buckwheat seed as a staple food. The age-adjusted prevalence rate of hyperglycaemia in Kulun participants was $1.56 \%$ (95\% CI: $0.78 \%, 2.34 \%$ ), whereas that in Kezhuohou participants was 7.70\% (95\% CI: $6.01 \%, 9.39 \%$ ). The difference was significant $(\mathrm{P}<0.01)$. 6. The results indicated that the consumption of buckwheat seed possessed preventative effect for hyperglycaemia in the Pastureland Mongolian population [79].

\section{Anticancer effect:}

An anticancer peptide with a molecular mass of approximately $4 \mathrm{kDa}$ was isolated from buckwheat. It inhibited proliferation of Hep G2 (hepatoma) cells, L1210 (leukemia) cells, breast cancer (MCF-7) cells, and liver embryonic WRL 68 cells with an $\mathrm{IC}_{50}$ of 33, 4, 25, and 37 microM, respectively. On the other hand, the peptide was unable to evoke a mitogenic response from splenocytes or induce nitric oxide production by macrophages [92]. The antitumor effects of tartary buckwheat protein fractions were studied against human mammary cancer cell Bcap37 with MTT assay. The fraction of a protein of tartary buckwheat TBWSP31 showed that it possessed high time- and concentration- dependent antitumor effects [69]. The in vitro and in vivo anti-tumoral effects of recombinant buckwheat trypsin inhibitor was studied on hepatic cancer cells with investigation of the mechanism of apoptosis involved. Apoptosis in the H22 cell line induced by recombinant buckwheat trypsin inhibitor was identified using MTT assays, DNA electrophoresis, flow cytometry, morphological observation of the nuclei, measurement of cytochrome $\mathrm{C}$ and assessment of caspase activation. It was identified that recombinant buckwheat trypsin inhibitor decreases cell viability by inducing apoptosis, as evidenced by the formation of apoptotic bodies and DNA fragmentation. Recombinant buckwheat trypsin inhibitor -induced apoptosis occurred in association with mitochondrial dysfunction, leading to the release of cytochrome $\mathrm{C}$ from the mitochondria to the cytosol, as well as the activation of caspase-3, -8 and -9 [93]. Lectin from tartary buckwheat seeds was purified and characterized and its effect of inducing apoptosis in human leukemia U937 cells was studied. The results of the treatment of human leukemia U937 cells with tartary buckwheat-derived lectin in doses of $12.5,25,50$, and $100 \mu \mathrm{g} / \mathrm{ml}$ showed that tartary buckwheat-derived lectin induced apoptosis in a dose-dependent manner. However, lectin from tartary buckwheat seeds also hem-agglutinated both human and animal erythrocytes and showed preference for blood type $\mathrm{O}$ and the rabbit blood type. Tartary buckwheat-derived lectin was active at up to $60^{\circ} \mathrm{C}$, and it was acid- and alkali-stable. Tartary buckwheat-derived lectin $(25 \mu \mathrm{g} / \mathrm{ml})$ combined with $5 \times 10^{-5} \mathrm{M}$ rhIL-4 promotes maturation and proliferation of peripheral blood dendritic cells (DCs), which was stronger than that promoted by rhTNF- $\alpha(20 \mathrm{ng} / \mathrm{ml})$. Exposure of DCs to $50 \mu \mathrm{g} / \mathrm{ml}$ tartary buckwheat-derived lectin for $48 \mathrm{~h}$ resulted in extensive upregulation of maturation markers CD83 and CD40. These tartary buckwheat-derived 
lectin -DCs were capable of producing several pro-inflammatory cytokines such as interleukin-10 (IL-10) and interleukin-12 (IL-12) [94]. Female rats were examined for the effects of feeding buckwheat protein extract on the development of mammary tumor caused by administration of 7,12- dimethylbenz [alpha] anthracene. Buckwheat protein extract decrease the incidence of mammary tumors and serum estradiol. The anticarcinogenic effect was proposed to be mediated by the lowering of serum estradiol levels in buckwheat protein diet consuming animals [95]. The effect of consumption of buckwheat protein product (BWP) on 1,2-dimethylhydrazine (DMH)-inducedcolon tumor was studied in in rats. Male rats were fed diets containing either casein or BWP (net protein level, $200 \mathrm{~g} / \mathrm{kg}$ ) for 124 days. The rats were gavaged weekly with DMH $(20 \mathrm{mg} / \mathrm{kg}$ body) for the first $8 \mathrm{wk}$. Food intake and growth were unaffected by dietary manipulation. Dietary BWP caused a 47\% reduction in the incidence of colonic adenocarcinoma $(\mathrm{P}<0.05)$, but did not affect the incidence of colonic adenomas. Consumption of BWP significantly reduced cell proliferation and expression of c-myc and c-fos proteins in colonic epithelium [96].

\section{Antimicrobial effects:}

The antibacterial activity of buckwheat hulls extract (four concentrations, ranging from 6.25 to 100 $\mathrm{mg} / \mathrm{ml}$ ) was studied against three species of Gram-positive (Bacillus cereus, Staphylococcus aureus, Enterococcus faecalis) and three species of Gram-negative bacteria (Salmonella choleraesuis, Escherichia coli and Proteus mirabillis). Buckwheat hulls extract exhibited higher antimicrobial activity against Gram-positive than Gram-negative bacteria. Buckwheat hulls extract in concentration of $50 \mathrm{mg} / \mathrm{ml}$ produced zone of inhibition of $13.3 \pm 0.88 \mathrm{~mm}$ against Bacillus cereus, $13.3 \pm 0.57 \mathrm{~mm}$ against Enterococcus faecalis and $11.6 \pm 0.88$ $\mathrm{mm}$ against Staphylococcus aureus. The same concentration of buckwheat hulls extract exerted lower inhibition zones against Gram-negative bacteria [97].An antifungal peptide with a molecular mass of approximately $4 \mathrm{kDa}$ was isolated from buckwheat. It inhibited mycelial growth of Fusarium oxysporum and Mycosphaerella arachidicola with an $\mathrm{IC}_{50}$ of 35 and 40 microM, respectively. Its antifungal activity was stable between 0 and 70 degrees $\mathrm{C}$, and between $\mathrm{pH}$ 1.0/2.0 and 13 [92].

A peptide with a molecular mass of approximately $4 \mathrm{kDa}$ was isolated from buckwheat. It inhibited HIV-1 reverse transcriptase with an $\mathrm{IC}_{50}$ of 5.5 microM [92].

\section{Wound healing effect:}

The efficacy of an ointment of honey bee and Fagopyrum esculentum was evaluated in the management of large dermal wound in a male rabbit. The wound was covered entirely by honey and then the fine powder of buckwheat grains was added. The treatment was applied once a day until complete epithelization has taken place. The results showed a complete resorption of inflammatory exudate of wound at $4^{\text {th }}$ day. The percentage of wound contraction has shown a rate of $5.55 \%$ at the $4^{\text {th }}$, increased to 32.22 and $71.48 \%$ at days 7 and 11 and it reached $99.53 \%$ at the $26^{\text {th }}$ days. The epithelization period was 27 days with a mean healing rate of $200 \mathrm{~mm}^{2} /$ day [98].

\section{Antistress effect:}

The antistress potential of extracts of Fagopyrum esculentum (100 mg/kg ) was evaluated using forced swimming endurance test. It was found that extracts significantly $(\mathrm{p}<0.001)$ increases swimming time in rats. they also showed significant $(\mathrm{p}<0.001)$ decreased in blood glucose, cholesterol, triglyceride, plasma cortisol and BUN levels as compared to control stress group [99].

\section{Effect on memory:}

The protective effects of buckwheat hull extract was investigated against toxicant-induced spatial memory impairment and hippocampal neuron injury in rats. The impairment of spatial memory and the decrease in the hippocampal weight were observed after the, trimethyltin administration $(8 \mathrm{mg} / \mathrm{kg} \mathrm{bw}$, orally to 6-week old rats). Prolonged supplementation of buckwheat hull extract seemed to reverse these, trimethyltin -induced toxic effects, and also improved the spatial memory of rats. The authors concluded that the buckwheat hull extract supplementation of foods enhanced the spatial memory of rats and possessed protective effects against hippocampal neurodegeneration accompanied by spatial memory impairment [100].

\section{Photoprotective effect:}

The photoprotective properties of the extract were compared to those of a commercial UV absorber. The photoprotective properties of the extract were examined by the inhibition of the photosensitized lipid peroxidation of linolic acid. The extract prevented more effectively the UV-induced peroxidation of linolic acid than rutin itself or the commercial UV absorber. The use of the extract from buckwheat herb was more beneficial than the use of pure rutin because of the presence of minor phenolic compounds in the extract [61]. 
Hypersensitivity was recorded with ingestion or inhalation of buckwheat allergen, it caused immediate manifestation of symptoms including urticaria, wheezing, dyspnea, anaphylactic shock, which was considered to be IgE-mediated type I hypersensitivity. The immuno-reactivity to purified buckwheat protein was investigated in sera of patients with buckwheat allergy by enzyme-linked immunosorbent assay and immunoblotting method. The incidence of positive RAST value to buckwheat was $80 \%$ in the patients and $66.6 \%$ in the RAST-positive controls, whereas the RAST-negative controls showed all negative. The sera of both patients and RAST-positive controls showed significantly higher levels of specific IgG antibodies against salt-soluble and salt-insoluble fractions of buckwheat protein than the RAST-negative controls [101].

Buckwheat allergy was one of the most severe food allergies. The Young female mice were sensitized and challenged intragastricly with fresh buckwheat flour $(1,5,25 \mathrm{mg} / \mathrm{dose}$ of proteins) mixed in cholera toxin, followed by intragastric challenge. Anaphylactic reactions, antigen-specific antibodies, splenocytes proliferation assays and cytokine productions were evaluated. Oral buckwheat challenges of sensitized mice provoked anaphylactic reactions such as severe scratch, perioral/periorbital swellings, or decreased activity. Reactions were associated with elevated levels of buckwheat specific IgE antibodies. Splenocytes from buckwheat allergic mice exhibited significantly greater proliferative responses to buckwheat than non-allergic mice. Buckwheatstimulated IL-4, IL-5, and INF-gamma productions were associated with elevated levels of buckwheat-specific IgE in sensitized mice. $1 \mathrm{mg}$ and $5 \mathrm{mg}$ dose of sensitization produced almost the same degree of Th2-directed immune response [102]. Buckwheat (BW) was recognized as a common food allergen in many places in the world. The serologic findings of buckwheat food allergy and the characterization of its major allergenic components were analysed. Nineteen BW-allergic subjects with symptoms after BW ingestion and 15 asymptomatic control subjects with positive skin prick test to BW were recruited. Allergenic components of BW were analyzed by IgE immunoblotting, periodate oxidation, two-dimensonal PAGE, and sequencing of $\mathrm{N}$ terminal amino acids. From the BW-allergic patients and asymptomatic controls. The prevalence of IgE binding to $24-\mathrm{kDa}$ (pI 8.3), 16-kDa (pI 5.6), and 9-kDa (pI 5.0/ 6.0) allergens was higher than 50\% in $\mathrm{BW}$-allergic and asymptomatic subjects. However, the specific IgE to split 19-kDa (pI 6.5/7.0) allergens were more specifically found in BW-allergic patients than in asymptomatic subjects (78\% vs $7 \%$ ). N-terminal amino-acid sequences of $19-\mathrm{kDa}$ and 16-kDa allergens showed moderate and weak homology to the 19-kDa globulin protein of rice and alpha-amylase/trypsin inhibitor of millet, respectively. The N-terminus of the 9-kDa isoallergens were not different from each other and were identified as the reported trypsin inhibitors of BW. Attenuation of the IgE binding to the 9-kDa allergen was found with periodate oxidation [103].The mechanisms of adverse reactions after ingesting buckwheat were investigated. RAST for anti-buckwheat IgE, skin prick test, and proliferative responses of peripheral blood mononuclear cells to buckwheat were investigated in a patient. RAST and skin prick test for buckwheat protein were negative, skin patch testing for buckwheat protein elicited positive responses. Peripheral blood mononuclear cells of the patient responded to buckwheat protein [104].A case was reported of a 36-year-old man who experienced nausea, vomiting, urticaria, a sensation of throat closing, inability to speak, dyspnea, and dizziness shortly after ingesting a large portion of buckwheat that required emergency room treatment. In the previous 2 years he had experienced asthma, contact urticaria, allergic conjunctivitis, and allergic rhinitis from sleeping with a buckwheat pillow. Six months after the first ingestion reaction, the patient again experienced anaphylaxis requiring emergency treatment when he accidentally ate crackers with a small amount of buckwheat. Skin-prick testing showed a strong positive response to buckwheat, and a radio-allergosorbent assay test was highly positive to buckwheat [105].

\section{Conclusion:}

This review was design to highlight the chemical constituents and pharmacological effects of Fagopyrum esculentum as a promising plant for many pharmacological purposes as a results of effectiveness and safety.

\section{REFERENCES:}

[1] Al-Snafi AE. The pharmacological importance of Aloe vera- A review. International Journal of Phytopharmacy Research 2015; 6(1) : 28-33.

[2] Al-Snafi AE. Medicinal plants affected reproductive systems (part 2) - plant based review. Sch Acad J Pharm 2016; 5(5): 159-174.

[3] Al-Snafi AE. Medicinal plants with anticancer effects (part 2)- plant based review. Sch Acad J Pharm 2016; 5(5): 175-193.

[4] Al-Snafi AE. Antiparasitic, antiprotozoal, molluscicidal and insecticidal activity of medicinal plants (part 2) - plant based review. Sch Acad J Pharm 2016; 5(6): 194-207.

[5] Al-Snafi AE. Medicinal plants with antidiabetic effects (part 2): plant based review. IOSR Journal of Pharmacy 2016; 6(7): 49-61. 
[6] Al-Snafi AE. Medicinal plants with antioxidant and free radical scavenging effects (part 2): plant based review. IOSR Journal Of Pharmacy 2016; 6(7): 62-82.

[7] Al-Snafi AE. Medicinal plants with antimicrobial activities (part 2): Plant based review. Sch Acad J Pharm 2016; 5(6): 208-239.

[8] Al-Snafi AE. Medicinal plants with cardiovascular effects (part 2): plant based review. IOSR Journal of Pharmacy 2016; 6(7): 43-62.

[9] Al-Snafi AE. Detoxification capacity and protective effects of medicinal plants (part 2): plant based review. IOSR Journal of Pharmacy 2016; 6(7): 63-84.

[10] Al-Snafi AE. Beneficial medicinal plants in digestive system disorders (part 2): plant based review. IOSR Journal of Pharmacy 2016; 6(7): 85-92.

[11] Al-Snafi AE. Immunological effects of medicinal plants: A review (part 2). Immun Endoc \& Metab Agents in Med Chem 2016; 16(2): 100-121.

[12] Al-Snafi AE. Medicinal plants affected male and female fertility (part 1)- A review. IOSR Journal of Pharmacy 2016; 6(10): 11-26.

[13] Al-Snafi AE. Antiparasitic effects of medicinal plants (part 1)- A review. IOSR Journal of Pharmacy 2016; 6(10): 51-66.

[14] Al-Snafi AE. Antimicrobial effects of medicinal plants (part 3): plant based review IOSR Journal of Pharmacy 2016; 6(10): 67-92.

[15] Al-Snafi AE. The contents and pharmacological importance of Corchorus capsularis- A review. IOSR Journal of Pharmacy 2016; 6(6): 58-63.

[16] Al-Snafi AE. The chemical constituents and pharmacological effects of Convolvulus arvensis and Convolvulus scammonia- A review. IOSR Journal of Pharmacy 2016; 6(6): 64-75.

[17] Al-Snafi AE. Pharmacology and toxicology of Conium maculatum- A review. The Pharmaceutical and Chemical Journal 2016; 3(2):136-142.

[18] Al-Snafi AE. The constituents and pharmacology of Cnicus benedictus- A review. The Pharmaceutical and Chemical Journal 2016; 3(2):129-135.

[19] Al-Snafi AE. Medicinal importance of Colchicum candidum- A review. The Pharmaceutical and Chemical Journal 2016; 3(2):111-117.

[20] Al-Snafi AE. Nutritional value and pharmacological importance of citrus species grown in Iraq. IOSR Journal of Pharmacy 2016; 6(8): 76-108.

[21] Al-Snafi AE. Pharmacological activities of Cotoneaster racemiflorus- A review. The Pharmaceutical and Chemical Journal 2016; 3(2): 98-104.

[22] Al-Snafi AE. The pharmacological and toxicological effects of Coronilla varia and Coronilla scorpioides: A review. The Pharmaceutical and Chemical Journal 2016; 3(2): 105-114.

[23] Al-Snafi AE. The constituents and pharmacology of Corchorus aestuans: A review. The Pharmaceutical and Chemical Journal 2016; 3(4):208-214.

[24] Al-Snafi AE. The chemical constituents and pharmacological activities of Cymbopagon schoenanthus: A review. Chemistry Research Journal 2016; 1(5):53-61.

[25] Al-Snafi AE. Traditional uses, constituents and pharmacological effects of Cuscuta planiflora. The Pharmaceutical and Chemical Journal 2016; 3(4): 215-219.

[26] Al-Snafi AE. A review on Erodium cicutarium: A potential medicinal plant. Indo Am J P Sci 2017; 4(01): 110-116.

[27] Al-Snafi AE. Pharmacology of Echinochloa crus-galli - A review. Indo Am J P Sci 2017; 4(01): 117 122.

[28] Al-Snafi AE. The pharmacological potential of Dactyloctenium aegyptium- A review. Indo Am J P Sci 2017; 4(01): 153-159.

[29] Al-Snafi AE. Chemical constituents, pharmacological and therapeutic effects of Eupatorium cannabinum- A review. Indo Am J P Sci 2017; 4(01): 160-168.

[30] Al-Snafi AE. Nutritional and therapeutic importance of Daucus carota- A review. IOSR Journal of Pharmacy 2017; 7(2): 72-88.

[31] Al-Snafi AE. Chemical constituents and pharmacological effects of Dalbergia sissoo - A review. IOSR Journal of Pharmacy 2017; 7(2): 59-71.

[32] Al-Snafi AE. Medical importance of Datura fastuosa (syn: Datura metel) and Datura stramonium - A review. IOSR Journal of Pharmacy 2017; 7(2):43-58.

[33] Al-Snafi AE. A review on Dodonaea viscosa: A potential medicinal plant. IOSR Journal of Pharmacy 2017; 7(2): 10-21.

[34] Al-Snafi AE. The pharmacology and medical importance of Dolichos lablab (Lablab purpureus)- A review. IOSR Journal of Pharmacy 2017; 7(2): 22-30.

[35] Al-Snafi AE. Pharmacological and therapeutic importance of Desmostachya bipinnata- A review. Indo Am J P Sci 2017; 4(01): 60-66. 
[36] Al-Snafi AE. Chemical constituents and pharmacological effects of Eryngium creticum- A review. Indo Am J P Sci 2017; 4(01): 67-73.

[37] Al-Snafi AE. The pharmacology of Equisetum arvense- A review. IOSR Journal of Pharmacy 2017; 7(2): 31-42.

[38] Al-Snafi AE. Phytochemical constituents and medicinal properties of Digitalis lanata and Digitalis purpurea - A review. Indo Am J P Sci 2017; 4(02): 225-234.

[39] Al-Snafi AE. Therapeutic and biological activities of Daphne mucronata - A review. Indo Am J P Sci 2017; 4(02): 235-240.

[40] Al-Snafi AE. Pharmacological and therapeutic importance of Erigeron canadensis (Syn: Conyza canadensis). Indo Am J P Sci 2017; 4(02): 248-256.

[41] Al-Snafi AE. Eschscholzia californica: A phytochemical and pharmacological review. Indo Am J P Sci 2017; 4(02): 257-263

[42] Al-Snafi AE. Therapeutic properties of medicinal plants: a review of plants with anti-inflammatory, antipyretic and analgesic activity (part 1). Int J of Pharmacy 2015; 5(3): 125-147.

[43] Al-Snafi AE. Therapeutic properties of medicinal plants: a review of their immunological effects (part 1). Asian Journal of Pharmaceutical Research 2015; 5(3): 208-216.

[44] Al-Snafi AE. Therapeutic properties of medicinal plants: a review of their antibacterial activity (part 1). International Journal of Pharmacology and Toxicology 2015; 6(3): 137-158.

[45] Al-Snafi AE. Therapeutic properties of medicinal plants: a review of plants with antioxidant activity (part 1). International Journal of Pharmacology and Toxicology 2015; 6(3): 159-182.

[46] Al-Snafi AE. Therapeutic properties of medicinal plants: a review of their respiratory effects ( part 1). International Journal of Pharmacological Screening Methods 2015; 5(2):64-71.

[47] Al-Snafi AE. Therapeutic properties of medicinal plants: a review of their antiviral activity (part 1). International Journal of Pharmacological Screening Methods 2015; 5(2): 72-79.

[48] Al-Snafi AE. Therapeutic properties of medicinal plants: a review of plants with cardiovascular effects (part 1). Int J of Pharmacology \& Toxicology 2015; 5(3): 163-176.

[49] Al-Snafi AE. Therapeutic properties of medicinal plants: a review of medicinal plants with central nervous effects (part 1). Int J of Pharmacology \& Toxicology 2015; 5(3): 177-192.

[50] Al-Snafi AE. Medicinal plants possessed anti-inflammatory antipyretic and analgesic activities (part 2)plant based review. Sch Acad J Pharm 2016; 5(5): 142-158.

[51] The plant list, a working list of all plant species, Fagopyrum esculentum Moench, http://www.theplantlist.org/tpl/record/kew-2807310.

[52] ITIS, Fagopyrum esculentum, http :// www .itis. gov/ servlet/ SingleRpt / SingleRpt? search _topic $=$ TSN\&search_value $=502589$

[53] U.S. National Plant Germplasm System, Taxon: Fagopyrum esculentum Moench. https://npgsweb.arsgrin.gov/gringlobal/taxonomydetail.aspx?16528

[54] Anne-Laure J, Valérie C. Jean-Marie K, Jean-François L and Muriel Q. Is buckwheat (Fagopyrum esculentum Moench) still a valuable crop today? The European Journal of Plant Science and Biotechnology 2012; 6 (Special Issue 2): 1-10.

[55] Flora of China, Fagopyrum esculentum Moench, Methodus. 290. 1794., http://www. efloras.org/florataxon.aspx?flora_id=2\&taxon_id=200006709

[56] Ratan P and Kothiyal P. Fagopyrum esculentum Moench (common buckwheat) edible plant of Himalayas: A review. Asian Journal of Pharmacy and Life Science 2011; 1(4): 426-442.

[57] Campbell CG. Buckwheat, Fagopyrum esculentum Moench. promoting the conservation and use of underutilized and neglected crops. 19. Institute of Plant Genetics and Crop Plant Research, Gatersleben/ International Plant Genetic Resources Institute, Rome, Italy 1997.

[58] Abbasi R, Janjua S, Rehman A, William K and Khan SW. Some preliminary studies on phytochemichals and antioxidant potential of Fagopyrum esculentum cultivated in Chitral, Pakistan. The Journal of Animal \& Plant Sciences 2015; 25(3 Supp. 2): 576-579.

[59] Skrabanja V, Kreft I, Golob T, Modic M, Ikeda S, Ikeda K, Kreft S, Bonafaccia G, Knapp M and Kosmelj K. Nutrient content in buckwheat milling fractions. Cereal Chemistry 2004; 81(2): 172-176.

[60] Bai CZ, Feng ML, Hao XL, Zhong QM, Tong LG and Wang ZH. Rutin, quercetin, and free amino acid analysis in buckwheat (Fagopyrum) seeds from different locations. Genet Mol Res 2015; 14(4): 1904019048.

[61] Hinneburg I, Kempe S, Httinger RH and Neubert RHH. Antioxidant and photoprotective properties of an extract from buckwheat herb (Fagopyrum esculentum Moench). Pharmazie 2006; 6(3): 237-240.

[62] Kim HJ, Park KJ and Lim JH. Metabolomic analysis of phenolic compounds in buckwheat (Fagopyrum esculentum M.) sprouts treated with methyl jasmonate. J Agric Food Chem 2011;59(10):5707-5713. 
[63] Watanabe M. Catechins as antioxidants from buckwheat (Fagopyrum esculentum Moench) groats. J Agric Food Chem 1998; 46 (3): 839-845.

[64] Steadmana KJ, Fullerb DJ and Obendorfa RL. Purification and molecular structure of two digalactosyl D-chiro-inositols and two trigalactosyl D-chiro-inositols from buckwheat seeds. Carbohydr Res 2001; 331: 19-25.

[65] Jing R, Li HQ, Hu CL, Jiang YP, Qin LP, and Zheng CJ. Phytochemical and pharmacological profiles of three Fagopyrum buckwheats. Int J Mol Sci 2016; 17(4): 589.

[66] Zheng F, Song QB, Qiang GR, Sun PL, Zhu XY and Chen DX. GC/MS analysis of fatty acid in Fagopyrum esculentum seed oil. Food Sci 2004; 25: 267-269.

[67] Cho JY, Moon JH, Kim HK, Ma SJ, Kim SJ, Jang MY, Kswazoe K, Takaishi Y and Park KH. Isolation and structural elucidation of antimicrobial compounds from buckwheat hull. J Microbiol Biotechnol 2006; 16: 538-542.

[68] Damjan J, Dragana K, Samo K and Helena P. Identification of buckwheat (Fagopyrum esculentum Moench) aroma compounds with GC-MS. Food Chem 2009; 112: 120-124.

[69] Xiao-na G and Hui-yuan Y. Isolation, purification and structure analysis of antitumor protein from tartary buckwheat. Food Science 2007-07, http://en.cnki. com.cn/Article_ en/CJFDTotalSPKX200707116.htm

[70] Przybylski R, Lee YC and Eskin NAM. Antioxidant and radical-scavenging activities of buckwheat seed components. Journal Amer Oil Chem Soc 1998; 75(11): 1595-1601.

[71] Mukoda T, Sun B and Ishiguro A. Antioxidant activities of buckwheat hull extract toward various oxidative stress in vitro and in vivo. Biol Pharm Bull 2001; 24(3): 209-213.

[72] van den Berg AJ, van den Worm E, van Ufford HC, Halkes SB, Hoekstra MJ and Beukelman CJ. An in vitro examination of the antioxidant and anti-inflammatory properties of buckwheat honey. $\mathrm{J}$ Wound Care 2008; 17(4): 176-178.

[73] Gandhi A and Dey G. Fermentation responses and in vitro radical scavenging activities of Fagopyrum esculentum. Int J Food Sci Nutr 2013; 64(1): 53-57.

[74] Lee YJ, Kim KJ, Park KJ, Yoon BR, Lim JH and Lee OH. Buckwheat (Fagopyrum esculentum M.) sprout treated with methyl jasmonate (MeJA) improved anti-adipogenic activity associated with the oxidative stress system in 3T3-L1 adipocytes. Int J Mol Sci 2013; 14(1): 1428-1442.

[75] Gheldof N, Wang XH and Engeseth NJ. Buckwheat honey increases serum antioxidant capacity in humans. J Agric Food Chem 2003; 51(5): 1500-1505.

[76] Ishii S, Katsumura T, Shiozuka C, Ooyauchi K, Kawasaki K, Takigawa S, Fukushima T, Tokuji Y, Kinoshita M, Ohnishi M, Kawahara M and Ohba K. Anti-inflammatory effect of buckwheat sprouts in lipopolysaccharide-activated human colon cancer cells and mice. Biosci Biotechnol Biochem 2008; 72(12): 3148-3157.

[77] Kyung-Hwa K. Fagopyrum esculentum extract suppresses the release of inflammatory mediator and proximal signal events in $\mathrm{F}_{\mathrm{CE}}$ RI-mediated RBL-2H3 cell activation. The Korean Association of Oriental Medical Physiology 2012; 26(4): 469-474

[78] Kim CD, Lee WK, No KO, Park SK, Lee MH, Lim SR and Roh SS. Anti- allergic action of buckwheat (Fagopyrum esculentum Moench ) grain extract. Int Immunopharmacol 2003; 3(1): 129-136.

[79] Zhang HW, Zhang YH, Lu MJ, Tong WJ and Cao GW. Comparison of hypertension, dyslipidaemia and hyperglycaemia between buckwheat seed-consuming and non-consuming Mongolian-Chinese populations in Inner Mongolia, China. Clin Exp Pharmacol Physiol 2007; 34(9): 838-844.

[80] Chu JX, Li GM, Gao XJ, Wang JX and Han SY. Buckwheat rutin inhibits angII-induced cardiomyocyte hypertrophy via blockade of CaN-dependent signal pathway. Iran J Pharm Res 2014; 13(4): 1347-1355.

[81] Ma MS, Bae IY, Lee HJ and Yang CB. Purification and identification of angiotensin I converting enzyme inhibitory peptide from buckwheat (Fagopyrum esculentum Moench). Food Chem 2006; 96: 3642.

[82] Ihme N, Kiesewetter F, Jung F, Hoffmann KH, Birk A, Muller A and Grutzner KI. Leg oedema protection from a buckwheat herb tea in patients with chronic venous insuffenciency: a single, randomized. double blind, placebo-controlled clinical trial. Eur J Clin Pharmocol 1996; 50: 443-447

[83] Tomotake H, Yamamoto N, Yanaka N, Ohinata H, Yamazaki R, Kayashita J and KatoN.High protein buckwheat flour suppresses hypercholesterolemia in rats and gallstone formation in mice byhypercholesterolemic diet and body fat in rats because of its low protein digestibility. Nutrition 2006; 22(2): 166-173.

[84] Tomotake H, Kayashita J and Kato N. Hypolipidemic activity of common (Fagopyrum esculentum Moench) and tartary (Fagopyrum tataricum Gaertn.) buckwheat. J Sci Food Agric 2015;95(10):1963-1967.

[85] Vogrinčič M, Kreft I, Filipič M and Zegura B. Antigenotoxic effect of tartary (Fagopyrum tataricum) and common (Fagopyrum esculentum) buckwheat flour. J Med Food 2013;16(10):944-952. 
[86] Jin-Xiu C, Zhi-Lu W and Shu-Ying H. The effects of total flavonoids from buckwheat flowers and leaves on renal damage and PTP1B expression in type 2 diabetic rats. Iran J Pharm Res 2011; 10(3): 511-517.

[87] Yokozawa T, Kim HY, Nonaka G and Kosuna K. Buckwheat extract inhibits progression of renal failure. J Agric Food Chem 2002; 50(11): 3341-3345.

[88] Yokozawa T, Fujii H, Kosuna K and Nonaka G. Effects of buckwheat in a renal ischemia-reperfusion model. Biosci Biotechnol Biochem 2001; 65(2): 396-400.

[89] Hosaka T, Nii Y, Tomotake H, Ito T, Tamanaha A, Yamasaka Y, Sasaga S, Edazawa K, Tsutsumi R, Shuto E, Okahisa N, Iwata S and Sakai T. Extracts of common buckwheat bran prevent sucrose digestion. J Nutr Sci Vitaminol (Tokyo) 2011; 57(6): 441-445.

[90] Curran JM, Stringer DM, Wright B, Taylor CG, Przybylski R and Zahradka P. Biological response of hepatomas to an extract of Fagopyrum esculentum M. (buckwheat) is not mediated by inositols or rutin. J Agric Food Chem 2010; 58(5): 3197-3204.

[91] Skrabanja V, Helena G M. Elmståhl L, Kreft I and Björck IME. Nutritional properties of starch in buckwheat products: studies in vitro and in vivo. J Agric Food Chem 2001; 49 (1): 490-496.

[92] Leung EH and Ng TB. A relatively stable antifungal peptide from buckwheat seeds with antiproliferative activity toward cancer cells. J Pept Sci 2007; 13(11): 762-767.

[93] Bai CZ, Feng ML, Hao XL, Zhao ZJ, Li YY and Wang ZH. Anti-tumoral effects of a trypsin inhibitor derived from buckwheat in vitro and in vivo. Mol Med Rep 2015; 12(2): 1777-1782.

[94] Bai CZ, Ji HJ, Feng ML, Hao XL, Zhong QM, Cui XD and Wang ZH. Stimulation of dendritic cell maturation and induction of apoptosis in lymphoma cells by a stable lectin from buckwheat seeds. Genet Mol Res 2015; 14(1): 2162-2175.

[95] Kayashita J, Shimaoka I, Nakajoh M, Kishida N and Kato N. Consumption of a buckwheat protein extract retards 7,12-dimethylbenz[a]anthracene-induced mammary carcinogenesis in rats. Biosci Biotechnol Biochem 1999; 63: 1837-1839.

[96] Liu Z, Ishikawa W, Huang X, Tomotake H, Kayashita J, Watanabe H and Kato N. A buckwheat protein product suppresses 1,2-dimethylhydrazine-induced colon carcinogenesis in rats byreducing cell proliferation. J Nutr 2001; 131(6): 1850-1853.

[97] Čabarkapa IS, Sedej IJ, Sakač MB, Šarić LC and Plavšić DV. Antimicrobial activity of buckwheat (Fagopyrum esculentum Moench) hulls extract. Food Processing, Quality and Safety 2008; 4: 159-163.

[98] Zouhir D. Efficacy of honey bee and Fagopyrum esculentum Moench ointment in the treatment of sub chronic wound in rabbits: A case control study. American Journal of Animal and Veterinary Sciences 2014; 9 (1): 14-18.

[99] Kothiyal P and Ratan P. Antistress effect of Fagopyrum esculentum in rats subjected to forced swimming endurance test. Pharmacologyonline 2011; 3: 290-296.

[100] Koda T, Kuroda Y, Ueno Y, Kitadate K and Imai H. Protective effects of buckwheat hull extract against experimental hippocampus injury induced by trimethyltin in rats. Nihon Eiseigaku Zasshi 2008; 63(4): 711-716.

[101] Takahashi Y. Analysis of immune responses in buckwheat allergy. Arerugi 1996; 45(12): 1244-1255.

[102] Lee SY, Oh S, Lee K, Jang YJ, Sohn MH, Lee KE and Kim KE. Murine model of buckwheat allergy by intragastric sensitization with fresh buckwheat flour extract. J Korean Med Sci 2005; 20(4): 566-572.

[103] Park JW, Kang DB, Kim CW, koh SH, Yum HY, Kim KE, Hong CS and Lee KY. Identification and characterization of the major allergens of buckwheat. Allergy 2000; 55(11): 1035-1041.

[104] Agata H, Kondo N, Fukutomi O, Takemura M, Tashita H, Kobayashi Y, Shinoda S, Nishida T, Shinbara $\mathrm{M}$ and Orii T. Pulmonary hemosiderosis with hypersensitivity to buckwheat. Ann Allergy Asthma Immunol 1997; 78(2): 233-237.

[105] Stember RH. Buckwheat allergy. Allergy Asthma Proc 2006; 27(4): 393-395. 